\title{
Acute Effects of Ammoniac Nitrogen on Marine Copepod Acartia pacifica When Exposed to Different Temperature Conditions
}

\author{
Jiagen Shang \\ College of Marine Life Science, Ocean University of China \\ Qingdao 266003, Shandong, China
}

\begin{abstract}
Mengxue Lu (Correspondence)
Basic Education Group of Shandong Normal University, Jinan 250014, Shandong, China

College of Marine Life Science, Ocean University of China, Qingdao 266003, China

E-mail: marineecology@163.com
\end{abstract}

Qi Yu

Qingdao No.2 Middle School of Shandong Province, 266071, China

Received: March 12, 2018 Accepted: March 31, 2018 Published: January 30, 2018

doi:10.5296/ast.v6i2.12940 URL: https://doi.org/10.5296/ast.v6i2.12940

\begin{abstract}
Acute toxicity of ammoniac nitrogen on marine copepod Acartia pacifica when exposed to different temperatures of $10^{\circ} \mathrm{C} \sim 25^{\circ} \mathrm{C}$ were performed under controlled lab conditions. The changing tendency of mortality was evaluated and the 48h LC50 was determined according to the observation. Results showed that the $48 \mathrm{~h}$ LC50 in different temperature gradients were for Pacific spindle daphnia $48 \mathrm{~h}$ - LC50 is $65.889 \mathrm{mg} / \mathrm{L}$ for $25^{\circ} \mathrm{C}, 134.214 \mathrm{mg} / \mathrm{L}$ for $20{ }^{\circ} \mathrm{C}$, $71.247 \mathrm{mg} / \mathrm{L}$ for $15^{\circ} \mathrm{C}$ and $27.318 \mathrm{mg} / \mathrm{L}$ for $10{ }^{\circ} \mathrm{C}$, respectively. Temperature seemed to exert impacts on the stress induced by ammoniac nitrogen, and the peak of $48 \mathrm{~h} \mathrm{LC}_{50}$ appeared in between $15{ }^{\circ} \mathrm{C}$ and $20^{\circ} \mathrm{C}$. The toxicity of ammonia showed a tendency to decrease with the increase of temperature before the peak while the was significantly enhanced with temperature increasing thereafter.
\end{abstract}

Keywords: Ammoniac nitrogen, temperature, acute toxicity, marine copepod, Acartia pacifica 


\section{Introduction}

Temperature is an important environmental factor in marine ecological environment. It has direct or indirect influence on many biological, physical and chemical processes on marine biota. The obtained data have shown that temperature can affect multiple aspects of copepods. Firstly, temperature would affect the species and the quantity of copepod in the marine ecosystem. The experimental studies on $\mathrm{f}$ temperature gradients on the population dynamics of copepods showed that the number of copepods increased with time increasing as the temperature drops below $30^{\circ} \mathrm{C}$ but decreased over time when the temperature was above $30^{\circ} \mathrm{C}$ (Aldridge et al., 1993). Secondly, the change of temperature could affect the metabolism of copepods. The environmental temperature played essential role in the metabolic rate of copepods. The metabolic rate increased significantly with temperature increased, and the oxygen consumption rate increased simultaneously. Cai (2011) reported that ratio between the primary production and the total respiratory rate increased by about 1.2-fold when the temperature increased from $25.2{ }^{\circ} \mathrm{C}$ to $26.4{ }^{\circ} \mathrm{C}$, and the system turnover rate increased by about 1.5 fold. Other reports had shown that the increased temperature enhance the respiratory rate of copepod. But there was a threshold of increment, and the exceeding of the value would result in the death of the individuals. Thirdly, temperature altered the reproductive process of copepod. The hatching rate, developmental period and the size of the individual were significantly affected, which finally led to the change of the population dynamics (Klein et al., 1995). Huang et al. (2008) found that the enhanced temperature could increase the growth of marine copepod in a certain range but would be greatly increased the death of larvae if the temperature was higher above the threshold. The fourth aspect was that temperature could impair the oxygen consumption and ammonia removal in copepods. Chen et al. (2001) studied the oxygen consumption of three species of copepods at different temperatures and found that their oxygen consumption rate and ammonia removal rate showed a trend of increase firstly and decrease thereafter. On the other hand, ammonia nitrogen is one of the serious and widespread pollutant in marine ecosystem. Excessive ammonia nitrogen in water can cause the occurrence of large area of blooms. Moreover, the consumption of ammonia nitrogen oxidation need large amounts of dissolved oxygen in water, which would lead to the hypoxia and deterioration of water (Wu et al, 2010).

Acartia pacifica is a warm species widely distributed in coastal area of China. It had short life cycle, moderate size and large biomass, and is preferable bait for many economic fish. It plays essential role in the material fluid and energy cycle in coastal ecosystem. We thus performed the present study, aiming at elucidating the effects of either ammoniac nitrogen, the main nutrient in coastal area, and the temperature alteration on the mortality of A. pacifica. Results would bring light on providing reliable data to support the accurate and practical application of ammonia nitrogen water quality baseline in China.

\section{Materials and Methods}

\subsection{Organism Collection and Cultivation of Acartia pacifica}

Adult A. pacifica individuals were collected from the shrimp pond located in Jiaonan 
$\left(36^{\circ} 15^{\prime} \mathrm{N}, 120^{\circ} 40^{\prime} \mathrm{E}\right)$, Qingdao, Shandong Province, using a small plankton net. The copepod samples were stored in $5 \mathrm{~L}$ polyvinyl chloride barrels and the bubbles were prevented when sealing the lid. Samples were quickly Quickly transfer to the lab (preferably within $2 \mathrm{~h}$ ) after sealing and avoided violent shaking during the transformation. Other organisms that fed on copepod, such as arrow worms, phytoplankton and jellyfish larvae, were picked out carefully from the medium and the culture system was transferred to the $2 \mathrm{~L}$ beaker containing raw seawater with continuous aeration. The whole culture system was kept at $20 \pm 1^{\circ} \mathrm{C}$ with a $12 \mathrm{~h}$ light:dark cycle in illuminating incubators, and the salinity was set at 30 . The strong and active individuals were chosen for further experiment. Copepod was fed with microalga Isochrysis galbana in exponential phase at an approximate concentration of $5.0 \times 10^{4}$ cells $/ \mathrm{mL}$.

\subsection{Experimental Design}

The experiment was conducted in clean beakers containing raw seawater, and each beaker had 15 A. pacifica individuals in it.Range-finding tests were conducted in the present study, and a serious ammoniac nitrogen at final concentrations of 4.76, 8.57, 15.43, 27.77, 49.98, 89.96, 161.94 and $291.48 \mathrm{mg} / \mathrm{L}$ were added into the respective beakers. Three paralleled groups were performed for each treatment. A separate group of filtered seawater without ammoniac nitrogen addition was used the blank control. The whole culture systems above prepared were exposed to different temperature conditions of $10,15,20$ and $25^{\circ} \mathrm{C}$, respectively. The cultivating conditions were the same as those described in 2.1 without other description and no feeding was performed during the experiment. The mortality of the copepod was observed and calculated with 48h after exposure, and the 48h-LC50 and its 95\% confidence limits were determined by PROBIT analysis. Mortality was calculated according to the following equation:

$$
\text { mortality }=\frac{\text { dead individuals }}{\text { total individuals }} \times 100 \%
$$

\subsection{Statistic Analysis}

SPSS Statistics 17.0 was used to analyze the data. The difference between the test and control results were analysed statistically with one-way analysis of variance (one-way ANOVA).

\section{Results}

When the experimental system was exposed to $10^{\circ} \mathrm{C}$, we found the no individual deaths occurred in the control group. however, the mortality increased steadily with concentration increasing, and reached the peak at group of $291.48 \mathrm{mg} / \mathrm{L}$. significance was observed between the groups higher than $15.43 \mathrm{mg} / \mathrm{L}$ as compared to the control $(\mathrm{P}<0.05)$.

Similar changing tendency was observed in groups of $15^{\circ} \mathrm{C}, 20^{\circ} \mathrm{C}$ and $25^{\circ} \mathrm{C}$. The mortality increased in a clear concentration-dependent manner, and significance was always appeared in higher concentration groups of 161.94 and $291.48 \mathrm{mg} / \mathrm{L}$ in all treatment as compared to the control $(\mathrm{P}<0.05)$. 

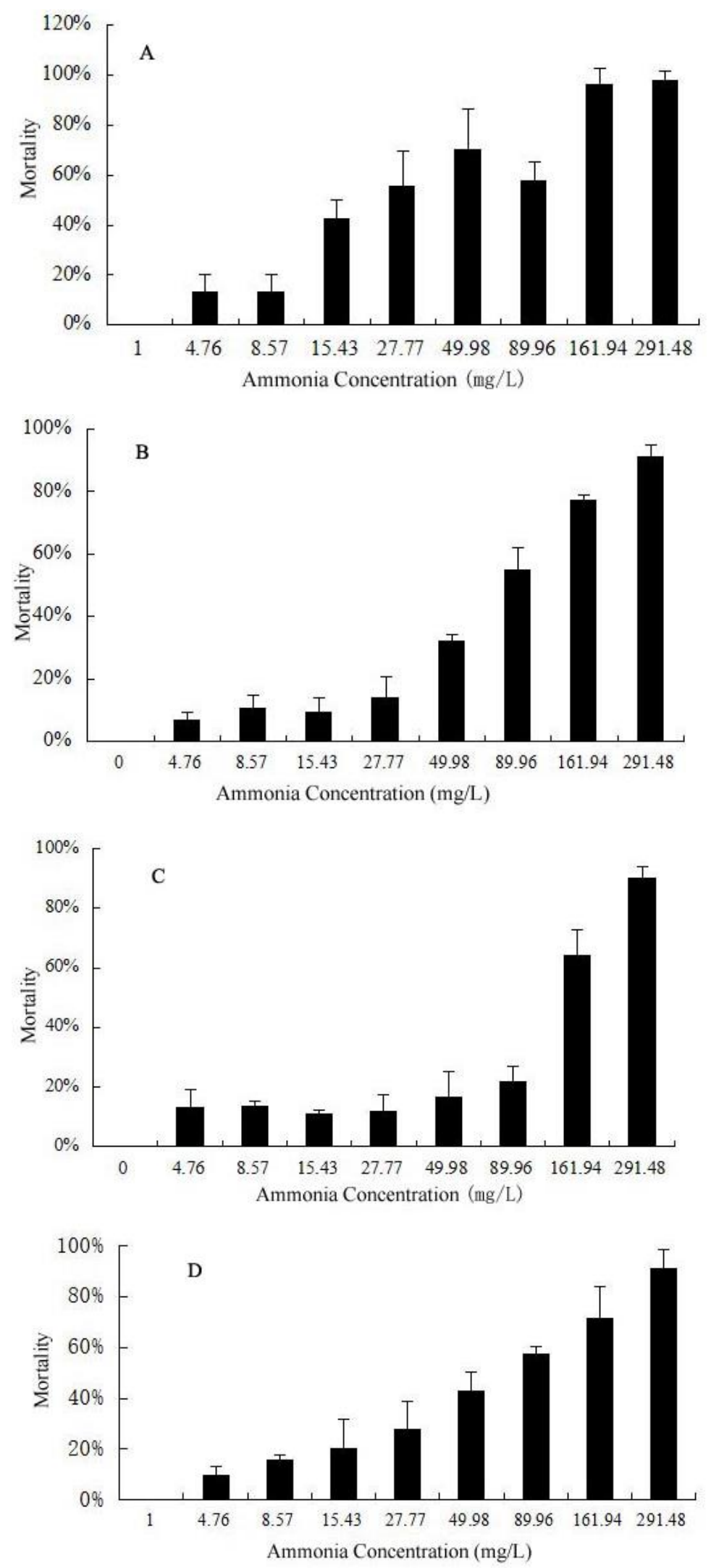

Figure 1. Effects of different concentrations of ammoniac nitrogen on mortality of A. pacifica at $48 \mathrm{~h}$ after exposure when exposed to different temperature conditions A: $10^{\circ} \mathrm{C} ; \mathrm{B}: 15^{\circ} \mathrm{C} ; \mathrm{C}: 20^{\circ} \mathrm{C} ; \mathrm{D}: 25^{\circ} \mathrm{C}$ 
Results were summarized in Tab.1. when combined considered the results we found that the higher tolerance of $A$. pacifica to ammoniac nitrogen was occurred in groups when exposure to $20^{\circ} \mathrm{C}$, and the most sensitivity was observed in groups of $10^{\circ} \mathrm{C}$. It seemed that a joint effect of both temperature and ammoniac nitrogen might occur in the present study. Relative higher or favorite temperature might enhance the tolerance of A. pacifica to the stress of ammoniac nitrogen.

Table 1. Parameters relating to the acute toxicity of ammoniac nitrogen when exposed to different temperature conditions

\begin{tabular}{ccccc}
\hline $\begin{array}{c}\text { Temperature } \\
\left({ }^{\circ} \mathrm{C}\right)\end{array}$ & $\begin{array}{c}48 \mathrm{~h}-\mathrm{LC}_{50} \\
(\mathrm{mg} / \mathrm{L})\end{array}$ & Regression curve & $\begin{array}{c}\text { The correlation } \\
\text { coefficient }\end{array}$ & $\begin{array}{c}\text { 95\% confidence } \\
\text { limit }(\mathrm{mg} / \mathrm{L})\end{array}$ \\
\hline 10 & 27.318 & $\mathrm{y}=0.1887 \ln (\mathrm{x})-0.1107$ & 0.9063 & $15.046-46.405$ \\
\hline 15 & 71.247 & $\mathrm{y}=0.003 \mathrm{x}+0.0921$ & 0.9051 & $49.321-110.914$ \\
\hline 20 & 134.214 & $\mathrm{y}=0.003 \mathrm{x}+0.0525$ & 0.9523 & $49.091-1520.624$ \\
\hline 25 & 65.889 & $\mathrm{y}=0.161 \ln (\mathrm{x})-0.1449$ & 0.9075 & $39.457-157.55$ \\
\hline
\end{tabular}

To further elucidate the suggestion above proposed, we made a correlation between $48 \mathrm{~h}-\mathrm{LC}_{50}$ and the temperature by using regression analysis (Fig.2). We found the peak of 48h-LC $\mathrm{C}_{50}$ peak appeared in between $15{ }^{\circ} \mathrm{C}$ and $20^{\circ} \mathrm{C}$. Before the peak, the toxicity of ammonia showed a tendency to decrease with the increase of temperature. Once the peak was reached, the toxicity of ammonia was significantly enhanced as the temperature continued to rise.

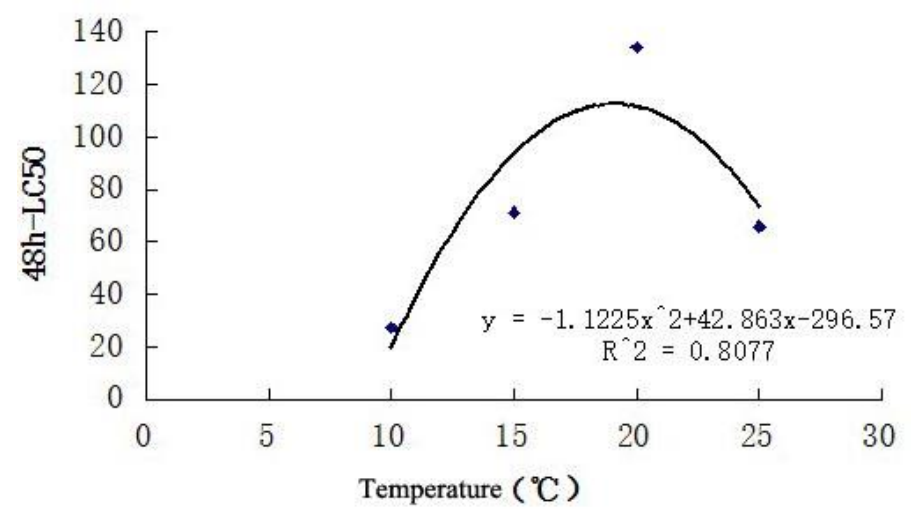

Figure 2. The regression curve of temperature on toxicity of ammonia.

\section{Discussion}

Marine environment, especially coastal environment is complex. Copepod have developed different strategies to cope with the environmental changes. Therefore, they would present different physiological states when exposed to different environmental conditions, and temperature is one of the essential factor determining the feeding behavior, metabolism and the process of development and reproduction of marine copepod. The obtained documents have shown that environmental factors can affect the feeding, metabolism and reproductive development of copepods. Temperature is the main factor affecting ammonia nitrogen toxicity mainly because it could change the concentration of non-ionic ammonia and finally result in quite different degree of toxicity in aquatic organisms. That's why summer is the 
main outbreak season of ammonia nitrogen toxicity in coastal North of China. We found similar result in the present study that relative higher temperature would enhance the toxicity of ammoniac nitrogen. According to the calculation formula of total ammonia and non-ionic ammonia percentage, it can be seen that, with the increase of temperature, the toxicity of ammonia is gradually enhanced. A. pacifica is a typical species in spring and summer, and the optimum temperature is within the range of $10 \sim 20{ }^{\circ} \mathrm{C}$. We found that although the temperature at a range of $10 \sim 20{ }^{\circ} \mathrm{C}$ would enhance the toxicity of ammonia nitrogen, the tolerance of A. pacifica to the stress increased. According to the correlation between temperature and the toxicity of ammoniac nitrogen, the tolerance of A. pacifica to ammoniac nitrogen increased steadily before reaching the optimal temperature, while decreased greatly when the temperature exceeded the optimal one. Therefore, the LC50 elevated as the temperature increased before reaching the optimal temperature. Once the temperature exceeded the optimum temperature, the tolerance of ammonia nitrogen will decrease significantly. At the same time, the toxicity of ammonia was increased with the increase of temperature. That was to say that the LC50 decreased when the temperature exceeded its optimality.

\section{References}

Aldridge, D. W., Payne, B. S., \& Miller, A. C. (1995). Oxygen consumption, nitrogenous excretion, and filtration rate of Dreissena polymorpha at acclimation temperatures between 20 and $32^{\circ} \mathrm{C}$. Canadian Journal of Fisheries \& Aquatic Sciences, 52(8), 1761-1767.

Breteler, K., Gonzalez, C. W., \& Schogt, R. S. (1995). Development of Pseudocalanus elongatus (Copepoda, Calanoida) cultured at different temperature and food conditions. Marine Ecology Progress Series, 119, 99-110.

Cai, Z. F., Yang, H., Jiao, J. P., Ding, L. L., Ding, J., Dai, G. X., \& Ma, J. L. (2011). Effects of thermal effluent on different size-fractionated marine plankton in the mesocosm ecosystem. Journal of Fisheries of China, 35(8), 1240-1246.

Chen, L. H., Chen, G., Li, S. J., \& Guo, D. H. (2001). Influence of tempetrature and salinity on respiratory rate of spring's dominant copepods in Xiamen Harbor. Journal of Oceanography in Taiwan Strait, 20(sup.), 184-189.

Huang, Y. (2008) Reproductive biology of Schmackeria poplesia and its use in ecotoxicological study of bis(tributyltin) oxide. Doctor Thesis: Ocean University of China.

Wu, F. C., Feng, C. L., Cao, Y. J., Zhang, R. Q., Li, H. X., Liao, H. Q., \& Zhao, X. L. (2011) Toxicity characteristic of zinc to freshwater biota and its water quality criteria. Asican Journal of Ecotoxicology, 6(4), 367-382.

\section{Copyrights}

Copyright for this article is retained by the author(s), with first publication rights granted to the journal.

This is an open-access article distributed under the terms and conditions of the Creative Commons Attribution license (http://creativecommons.org/licenses/by/4.0/) 